\title{
EUCLEA CRISPA: REVIEW OF ITS BOTANY, ETHNOMEDICINAL USES, AND PHARMACOLOGICAL PROPERTIES
}

\author{
ALFRED MAROYI* \\ Department of Botany, Medicinal Plants and Economic Development Research Centre, University of Fort Hare, Private Bag X1314, \\ Alice 5700, South Africa. Email: amaroyi@ufh.ac.za
}

Received: 05 February 2018, Revised and Accepted: 15 June 2018

\begin{abstract}
Euclea crispa is widely used as herbal medicine in southern Africa. This study was aimed at reviewing the botany, ethnomedicinal uses, and validated pharmacological properties of E. crispa. The literature search for information on ethnomedicinal uses and pharmacological activities of E. crispa was undertaken using databases such as web of science, BMC, science direct, elsevier, scopus, PubMed, and scielo. Other relevant literature sources included books, book chapters, websites, theses, conference papers, and other scientific publications. The extensive literature survey revealed that the bark, fruits, leaves, and roots of E. crispa are commonly used as herbal medicines for wounds, constipation, cough, stomach disorders, epilepsy, rheumatism, and diabetes. Pharmacological studies on E. crispa indicate that the species has amyloid $\beta$-peptide lowering effects, antibacterial, antidiarrheal, antifungal, and cell membrane disruption activities. E. crispa should be subjected to further scientific evaluations aimed at elucidating its chemical, pharmacological, and toxicological properties. Such detailed research should also include experimental animal studies, randomized clinical trials, and target-organ toxicity studies involving E. crispa extracts and its derivatives.
\end{abstract}

Keywords: Euclea crispa, Ethnopharmacology, Indigenous knowledge, Southern Africa, Traditional medicine.

(C) 2018 The Authors. Published by Innovare Academic Sciences Pvt Ltd. This is an open access article under the CC BY license (http://creativecommons. org/licenses/by/4. 0/) DOI: http://dx.doi.org/10.22159/ajpcr.2018.v11i10.25146

\section{INTRODUCTION}

Euclea crispa (Thunb.) Gürke is a member of the Ebenaceae or ebony family, which is pantropical in distribution with 600 species [1]. Phylogenetic studies carried out by Duangjai et al. [2] showed that family Ebenaceae consists of two subfamilies, Lissocarpoideae and Ebenoideae, and fourgenera, Diospyros L., Euclea Murr., Lissocarpa Benth. and Royena $\mathrm{L}$. The family Ebenaceae is a conspicuous forest component of tropical and subtropical areas of Africa and Asia, and a major source of several economically important products including timber (ebony) and edible fruits (persimmons) [2]. Ebenaceae is recognized by its fruits which appear such as little persimmons, often brownish, and seated on a persistent calyx [3]. A variety of constituents have been isolated and characterized from the family including naphthoquinones, terpenoids (especially lupanes, ursanes, oleananes, and taraxeranes), benzopyrones, polyphenols, and tannins [1]. The Ebenaceae family is characterized by the occurrence of 1, 4-naphthoquinonoid compounds, usually in dimeric forms, and often considered as taxonomic markers of the plant species belonging to this family [4,5]. At least 20 species of the Ebenaceae family are used as herbal medicines to expel intestinal worms and to treat and manage viral infections in the Asia Pacific region alone [3]. Some members of the Ebenaceae family are characterized by nutritious and delicious fruits which contain several bioactive phytochemicals such as tannins, proanthcyanidins, and flavonoids which impart a diverse array of pharmacological properties such as antioxidant activity, anticancer, antihypercholesterolemic, antidiabetic, cardioprotective, neuroprotective, antihypertensive, antiskin whitening, and antiaging activities [6]. Some naphthoquinones are marketed as pharmaceutical drugs and health products, such as atovaquone which is used as an alternative agent for malaria and Pneumocystis jiroveci pneumonia infection [6].

E. crispa and five other Euclea species, namely Euclea coriacea A. DC., Euclea divinorum Hiern, Euclea natalensis A. DC., Euclea racemosa L., and Euclea undulate Thunb. are widely used as herbal medicines in southern Africa [7-9]. Research by several authors [10-15] showed that E. crispa is an important medicinal plant used by both rural and urban communities throughout its native distributional range in southern Africa. According to Dlamini and Geldenhuys [16], E. crispa is regarded as a multipurpose plant species in Swaziland, popular for its edible fruits, different plant parts used as herbal medicines, fuelwood, charcoal, building material, and fences. E. crispa is used for dyeing mats and tanning leather in Malawi and South Africa [16,17], weaving baskets and as construction timber in South Africa [17,19]. According to Moteetee [20], E. crispa is mixed with Alepidea cordifolia L., Brunsvigia radulosa Herb., E. coriacea DC., and Lobelia dregeana and the mixture used for washing the divining bones to make them accurate. The fleshy part of the fruit is eaten by humans, birds, and animals, and the leaves and bark are eaten by game and livestock [11,17-30]. Leaves of E. crispa are used to brew an astringent medicinal tea often consumed as a tisane or herbal tea by the Khoi and San people of South Africa [31]. Bark, root, and stems of E. crispa are sold as herbal medicine in informal medicinal plant markets in the Gauteng province, South Africa [32]. It is within this context that the ethnomedicinal uses pharmacological activities of E. crispa were evaluated [33]. Therefore, this review is aimed at assessing if there is a correlation between the ethnomedicinal uses of E. crispa and documented phytochemical and pharmacological properties of the species. It is hoped that this ethnomedicinal and pharmacological information will highlight the value and importance of E. crispa as a potential source of a wide range of pharmaceutical products in southern Africa and will provide useful information to other researchers interested in the plant species.

\section{BOTANICAL PROFILE AND TAXONOMY OF E. UNDULATA}

E. crispa belongs to the Ebenaceae or Ebony family confined to Africa and Arabia, and in southern Africa, the family is represented by two genera, namely Euclea and Diospyros [17,34-40]. Euclea is a small genus of about 20 species, mostly trees, shrubs, or suffrutices with 16 of them recorded in southern Africa $[39,41]$. The genus name "Euclea" is derived from the Greek word "eukleia," which is derived from "eu" meaning "good," and "kleios" meaning report [42]. This is possibly in reference to the good quality wood of some Euclea species, particularly that of Euclea pseudebenus E. Mey. ex A. DC. [42]. The specific name is 
the Latin word "crispus" meaning "curled" or "undulating," in reference to the forms of the species with waxy leaf margins and the name of the subspecies "ovata" is based on the ovate leaves [11].

E. crispa is composed of two subspecies, E. crispa subsp. crispa and E. crispa subsp. ovata (Burch.) F.White. E. crispa grows in the open forest, on forest margins with scattered trees, open and dry Bushveld, riverine thickets, mountain, hill slopes, rocky ridges, and termite mounds [41,43]. The subspecies crispa is more widespread while subspecies ovata is confined to the drier parts of South Africa [11,39]. The two subspecies are separated mainly on the shape of their leaves. The leaves of subspecies crispa are variable in shape, rather small and narrow, apex broadly tapering or rounded and the margin slightly waxy, whereas those of subspecies ovata are ovate, apex sharply tapering, and the margin conspicuously waxy [11]

Both subspecies make dense, evergreen, leafy shrub, or small trees that are slender and robust up to $9 \mathrm{~m}$ tall with a single trunk up to $30 \mathrm{~cm}$ in diameter [11]. Main stem is multi-stemmed, stems crooked, densely branched, branches pale gray, covered in rusty granules when young, bark pale gray to brownish-gray, smooth to slightly rough, and cracking in blocks when older. The leaves are sub-opposite, rarely alternate, elliptic to ovate, margins entire, sometimes waxy, light bluish-green above, and paler bluish-green below. Flowers are small, greenish to yellow in color, borne in axils of leaves with male sprays longer than the female sprays [11]. Fruits which are small, hairy, round, reddish-brown become black when ripe and single-seeded. E. crispa has been recorded in Angola, Lesotho, Malawi, Mozambique, South Africa, Swaziland, Zambia, and Zimbabwe [41]. Most published literature, ethnobotany researchers, traditional healers, and local communities rarely separate E. crispa into specific subspecies, but E. crispa sensu lato is recognized, and the same approach has been adopted in this study.

\section{Ethnomedicinal uses}

The bark, fruits, leaves, and roots of E. crispa are reported to possess diverse medicinal properties and cure various human diseases throughout the distributional range of the species (Table 1). The root infusions of E. crispa are taken orally as a remedy for cough in South
Africa [41] and Zimbabwe [12,28,44], and for constipation in children in South Africa [15,45], Swaziland [46], and Zimbabwe [12]. Bark, fruit, leaf, and root infusions are taken orally for diabetes and epilepsy in South Africa [11,15,41,45], Swaziland [46] and Zimbabwe [12], stomach disorders $[15,41,45,47]$, and wounds in South Africa $[15,45]$. Diabetes is a metabolic disorder characterized by hyperglycemia resulting from defects in insulin secretion and action causing damage, dysfunction, and failure of different organs, especially the eyes, kidneys, nerves, heart, and blood vessels [48]. In Angola, root infusions of E. crispa are taken orally for fever, and root powder is applied to wounds [49]. In Lesotho, leaf infusions of E. crispa are used as a remedy for dysmenorrhea, painful menstruation, and purgative $[10,14,50]$, and the species is also widely used as charm to ward off bad omens and to divert hailstorm $[10,14,50]$. In Malawi, root decoction is applied to painful teeth as a remedy for toothache [51] while leaf and root infusion is taken orally as a remedy for malaria in Zambia [52]. In Swaziland, root infusions are taken orally as emetics and to prevent miscarriage [46], while in Zimbabwe, root infusion is taken orally for melanomas and venereal diseases and root powder rubbed on the body against measles $[12,44]$. In South Africa, the leaf, root, and stem infusions are taken orally as purgative, to enhance appetite, and a remedy for fever, flu, headache, malaria, painful menstruation, and rheumatism [7,11,15,41,45,53]. Research carried out by Semenya et al. $[54,55]$ showed that . crispa roots are taken orally mixed with roots of Citrullus lanatus (Thunb.) Matsum. and Nakai and Dodonaea viscosa (L.) Jacq. var. angustifolia (L.f.) J. G. Westas remedy for human immunodeficiency virus/acquired immunodeficiency syndrome which is a devastating epidemic in sub-Saharan Africa [56]. The chewed ends of the twigs of E. crispa serve as toothbrushes in South Africa [11,17,57] and Zimbabwe [58]. Some evidence exists that twig of some Euclea species, for example, E. natalensis and E. undulate used as a toothbrush in Botswana, Kenya, Mozambique, South Africa, Tanzania, and Zimbabwe [59-68] not only clean the teeth but also inhibit the growth of teeth attacking bacteria.

Based on ethnomedicinal information from literature, it appears that E. crispa is most commonly used as herbal medicine for wounds, constipation, cough, stomach disorders, epilepsy, rheumatism, and diabetes (Fig. 1). Several other Euclea species such as E. divinorum,

Table 1: Ethnomedicinal uses of $E$. crispa

\begin{tabular}{|c|c|c|c|}
\hline Use & Plant parts used & Country practiced & References \\
\hline Appetite enhancer & Leaf infusions taken orally & South Africa & 11 \\
\hline Charm & Leaf infusions used & Lesotho & 10 \\
\hline Constipation in children & Root infusions taken orally & South Africa, Swaziland, Zimbabwe & $12,15,45,46$ \\
\hline Cough & Root infusions taken orally & South Africa, Zimbabwe & $12,41,44,69,70$ \\
\hline Diabetes & Bark, fruit, leaf, and root infusions taken orally & South Africa, Swaziland, Zimbabwe & $11,12,15,41,45,46$ \\
\hline Dysmenorrhea & Leaf infusions taken orally & Lesotho & 10,71 \\
\hline Emetic & Root infusions taken orally & Swaziland & 46 \\
\hline Fever & Root infusions taken orally & Angola & 49 \\
\hline Fever & Leaf, root, and stem infusions taken orally & South Africa & 53 \\
\hline Flu & Leaf, root, and stem infusions taken orally & South Africa & 53 \\
\hline Headache & Leaf, root, and stem infusions taken orally & South Africa & 53 \\
\hline $\begin{array}{l}\text { Human immunodeficiency } \\
\text { virus/acquired } \\
\text { immunodeficiency } \\
\text { syndrome (HIV/AIDS) }\end{array}$ & $\begin{array}{l}\text { Roots taken orally mixed with roots of Citrullus } \\
\text { lanatus (Thunb.) Matsum. and Nakai and Dodonaea } \\
\text { viscosa (L.) Jacq. var. angustifolia (L.f.) J. G. West }\end{array}$ & South Africa & 54,55 \\
\hline Melanomas & Root decoction taken orally & Zimbabwe & 44,73 \\
\hline Measles & Root decoction taken orally & Zimbabwe & 12,44 \\
\hline Painful menstruation & Leaf decoction taken orally & Lesotho, South Africa & $10,14,41$ \\
\hline Prevent miscarriage & Root infusions taken orally & Swaziland & 46 \\
\hline Purgative & Bark and fruit infusion taken orally & Lesotho, South Africa & 11,50 \\
\hline Rheumatism & Bark, fruits, leaf, and root infusions taken orally & South Africa & $7,11,15,41,45$ \\
\hline Stomach disorders & Bark, leaf, and root infusions taken orally & South Africa & $15,41,45,47,74$ \\
\hline Toothache & Root decoction taken orally & Malawi & 51 \\
\hline Venereal diseases & Root infusion taken orally & Zimbabwe & 12 \\
\hline Wounds & Bark, leaf, and root infusion applied on wounds & Angola, South Africa & $15,45,49$ \\
\hline
\end{tabular}

E. crispa: Euclea crispa 


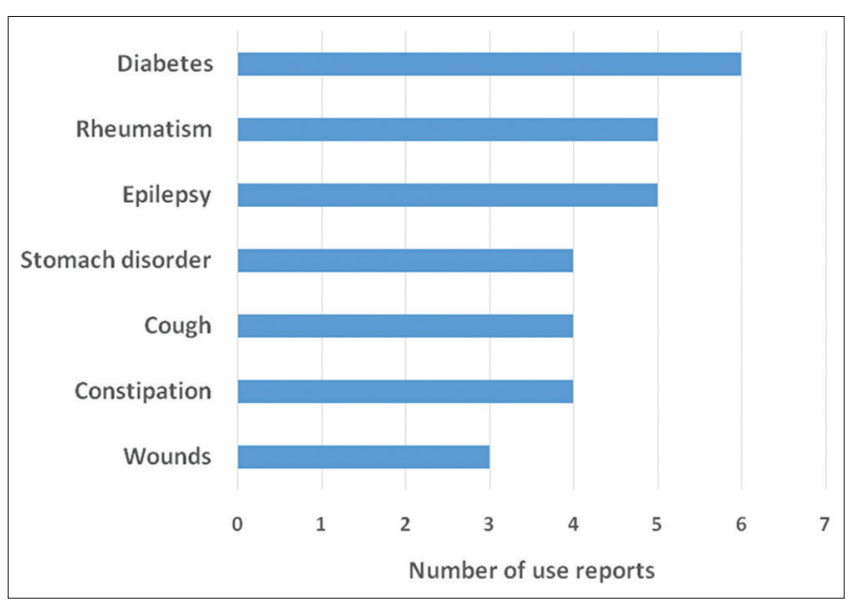

Fig. 1: Main ethnomedicinal uses of Euclea crispa in southern Africa. An ethnomedicinal use is only counted once per publication

E. natalensis, and E. undulata are widely used for constipation, cough, stomach disorders, and diabetes $[7,12,64,75]$. The bark, leaf, and root extracts of these species demonstrated antimicrobial, antioxidant, and hypoglycemic properties among other activities [7,64,75], corroborating the ethnomedicinal uses of the species.

\section{Phamacological properties \\ Amyloid $\beta$-peptide (A $\beta)$ production}

Kwon et al. [76] evaluated the in vitro A $\beta$-lowering effects of 3-oxooleanolic acid and natalenone isolated from root extracts of E. crispa using the sandwich ELISA protocol. These compounds were shown to inhibit the production of $A \beta$ from HeLa cells stably expressing Swedish mutant form of the amyloid precursor protein. These compounds 3-oxooleanolic acid and natalenone exhibited significant A $\beta 42$-lowering activity in a dose-dependent manner [76]. The compounds 3-oxooleanolic acid and natalenone lowered the production of $A \beta 42$ with half maximal inhibitory concentration $\left(\mathrm{IC}_{50}\right)$ values of approximately $10 \mu \mathrm{g} / \mathrm{ml}$ and $50 \mu \mathrm{g} / \mathrm{ml}$, respectively. The compound 3-oxo-oleanolic acid exhibited significant $\mathrm{A} \beta 42$ lowering activity in a dose-dependent manner. The production of $\mathrm{A} \beta 40$ was affected by treatment with 3-oxooleanolic acid at high concentration. Cell viability was not affected by treatment with 3-oxo-oleanolic acid at concentration up to $10 \mu \mathrm{g} / \mathrm{ml}$, whereas $25 \mu \mathrm{g} / \mathrm{ml}$ of 3-oxo-oleanolic acid inhibited cell proliferation by up to $60 \%$ of vehicle-treated cells [76]. Research by España et al. [77] showed that increased cerebrocortical $A \beta 42$ usually correlates with synaptic dysfunction which is associated with Alzheimer's disease. Therefore, further research is required in evaluating the detailed pharmacological processes involved in the reduced production of $A \beta$ by E. crispa extracts.

\section{Antibacterial activities}

Pretorius et al. [78] evaluated antibacterial activities of crude leaf extract of E. crispa at a concentration of $50 \mathrm{mg} / \mathrm{ml}$ against Agrobacterium tumefaciens, Clavibacter michiganense, Erwinia carotovora, Pseudomonas solanacearum, and Xanthomonas campestris using agar diffusion method with dimethyl dodecyl ammonium chloride (DDAC) as a positive control. E. crispa inhibited the growth of all five plant pathogenic test bacteria with inhibition zones of $10 \mathrm{~mm}$ or more for all test bacteria, and this compared favorably to that obtained with the standard bactericide, DDAC [78]. The E. crispa crude extract was fractionated by means of liquid-liquid extraction using four organic solvents, hexane, diethyl ether, chloroform, and ethyl acetate, and antibacterial activities of these compared with DDAC at equal concentrations of $1 \mathrm{mg} / \mathrm{ml}$ [78]. Only the ethyl acetate fraction of E. crispa showed antibacterial activity which compared favorably to the DDAC standard bactericide in terms of both inhibition range and zone size [78].
Pretorius et al. [79] evaluated antibacterial activities of flavonoids which included catechin, epicatechin, gallocatechin, hyperoside, and quercitrin isolated from E. crispa against Acinetobacter baumannii, Bacillus subtilis, Escherichia coli, Haemophilus influenza, Klebsiella pneumoniae, Moraxella catarrhalis, Pseudomonas aeruginosa, Staphylococcus aureus, Staphylococcus epidermidis, Streptococcus pneumoniae, and Streptococcus pyogenes using disk diffusion method. Compounds such as alkaloids, bitter principle, and phenolic and were active against the Gram-negative M. catarrhalis. The five flavonoid compounds, catechin, epicatechin, gallocatechin, hyperoside, and quercitrin showed antibacterial activities as individual compounds [79]. Of these flavonoids, epicatechin, and hyperoside were most active in inhibiting the growth of B. subtilis, H. influenza, K. pneumoniae, M. catarrhalis, and S. pneumonia [79].

Magama et al. [80] evaluated antibacterial activities of crude, n-hexane, diethyl ether, chloroform, and ethyl acetate leaf extracts of E. crispa against $A$. baumannii, B. subtilis, E. coli, $H$. influenzae, K. pneumoniae, Branhamella catarrhalis, P. aeruginosa, S. aureus, S. epidermidis, $S$. pneumoniae, and $S$. pyogenes using agar diffusion method. Most extracts demonstrated inhibition of growth of the pathogenic bacteria with zones of inhibition $>10 \mathrm{~mm}$, but neither of the extracts inhibited the growth of Gram-negative bacteria H. influenzae and K. pneumonia [80]. The ethyl acetate fraction gave the largest zones of inhibition and showed the broadest spectrum of activity by inhibiting the growth of 7 of the 11 (64\% of test organisms) human pathogenic bacteria, compared to only the 5 ( $45 \%$ of test organisms) inhibited by the crude extract [80].

Alayande et al. [81] evaluated antibacterial activities of E. crispa leaf extracts against Acinetobacter calcoaceticus anitratus, Aeromonas hydrophila, Bacillus pumilus, Enterococcus faecalis, E. coli, K. pneumoniae, Listeria spp., Plesiomonas shigelloides, Proteus vulgaris, P. aeruginosa, Salmonella typhi, Salmonella typhimurium, Shigella flexneri, Shigella sonnei, and S. aureus. The largest inhibition zone of $25.5 \pm 0.50 \mathrm{~mm}$ was obtained by ethyl acetate fraction against Aeromonas hydrophila at $10 \mathrm{mg} / \mathrm{ml}$. The lowest minimum inhibitory concentration (MIC) value of $0.16 \mathrm{mg} / \mathrm{ml}$ was exhibited by $\mathrm{n}$-butanol and ethyl acetate fractions against test bacteria which are comparable to MIC values of controls, streptomycin $(0.008 \mathrm{mg} / \mathrm{ml}$ and $0.125 \mathrm{mg} / \mathrm{ml})$, and tetracycline $(0.006 \mathrm{mg} / \mathrm{ml}$ and $0.025 \mathrm{mg} / \mathrm{ml})$ [81]. These findings somehow confirm the species' antibacterial potential and its usefulness in the treatment of stomach disorders [15,41,45,47], toothache [51], venereal diseases [12], and other microbial infections $[15,45,49]$.

\section{Antidiarrheal activities}

Alayande et al. [82] evaluated the in vitro antidiarrheal activities of hydro-methanol leaf extract of E. crispa and its fractions against diarrhea-causing E. coli bacteria and evaluated the extent and killing rate of the fractions. The antidiarrheal activities were assessed through susceptibility test, determination of MIC, and minimum bactericidal concentrations (MBC). The zones of inhibition exhibited by E. crispa extract at $20 \mathrm{mg} / \mathrm{ml}$ ranged between $17 \pm 0.28 \mathrm{~mm}$ and $22 \pm 0.00 \mathrm{~mm}$ [82]. The ethyl acetate and $\mathrm{n}$-butanol fractions showed inhibition zones that ranged between $18 \pm 0.00 \mathrm{~mm}$ and $22 \pm 0.00 \mathrm{~mm}$ at $10 \mathrm{mg} / \mathrm{ml}$ while the widest zones by $\mathrm{n}$-hexane, chloroform, and aqueous fractions were $20 \pm 0.00 \mathrm{~mm}, 22 \pm 0.00 \mathrm{~mm}$, and $18 \pm 0.58 \mathrm{~mm}$, respectively. The lowest MIC of ethyl acetate, $n$-butanol, and aqueous fractions was $0.08 \mathrm{mg} / \mathrm{ml}$ while that of n-hexane and chloroform was $0.16 \mathrm{mg} / \mathrm{ml}$. The lowest MBC by all fractions was $0.31 \mathrm{mg} / \mathrm{ml}$ except for the chloroform that was $1.25 \mathrm{mg} / \mathrm{ml}$. At $2 \times$ MIC after 120 min contact time, $100 \%$ mortality was achieved by the ethyl acetate fraction while $97.96 \%, 94.56 \%, 91.84 \%$, and $83.67 \%$ mortality was achieved by the n-butanol, n-hexane, aqueous, and chloroform fractions, respectively [82]. These results corroborate antidiarrheal applications of E. crispa which is widely used against stomach disorders in South Africa $[15,41,45,47]$.

\section{Antifungal activities}

Magama et al. [80] evaluated antifungal activities of crude, n-hexane, diethyl ether, chloroform, and ethyl acetate leaf extracts of E. crispa 
against while human pathogenic fungi were Candida albicans and Cryptococcus neoformans using agar diffusion method. All the extracts, with the exception of the hexane fraction, inhibited the growth of both human pathogenic fungi. The largest zones of inhibition were obtained with the crude extract, and $C$. albicans seemed slightly more sensitive to inhibition than $C$. neoformans as indicated by larger inhibition zones. Similarly, Alayande et al. [81] evaluated antifungal activities of E. crispa leaf extracts against C. albicans, Candida rugosa, C. neoformans, and Trichophyton mucoides. The fractions exhibited lowest MIC values of $0.31 \mathrm{mg} / \mathrm{ml}$ and the highest values of $1.25 \mathrm{mg} / \mathrm{ml}$ against test yeast isolate as compared with ketoconazole and nystatin with MIC values of $0.25 \mathrm{mg} / \mathrm{ml}$ and $0.13 \mathrm{mg} / \mathrm{ml}$ [80]. Hence, leaf extracts of E. crispa could be a good source of readily available drug against the aforementioned ailments in folklore remedy. The growth of $E$. coli, a common causative agent of diarrhea and urinary tract infections, and species of Salmonella and Shigella were also significantly inhibited by the extracts [81]. These findings validate traditional use of E. crispa as herbal medicine against antimicrobial infections.

\section{Cell membrane disruption}

The killing rate by the potent fractions was determined using B. pumilus, $K$. pneumoniae, and $C$. albicans as representative isolates. Alayande et al. [81] evaluated the effects of E. crispa leaf extracts on cell membrane disruption by determining the amount of proteins and nucleotides released from within the cells and scanning electron microscopy images of the membrane after $120 \mathrm{~min}$ of treatment. The fraction partitioned into n-butanol achieved absolute mortality against $B$. pumilus and K. pneumoniae after 90 and 120 min contact time, respectively, at $1 \times$ MIC. Total mortality was achieved by $\mathrm{n}$-hexane fraction against $B$. pumilus and K. pneumoniae after 90 and $120 \mathrm{~min}$, respectively, at $2 \times$ MIC. The ethyl acetate fraction achieved absolute mortality against both bacteria after $120 \mathrm{~min}$ at $2 \times$ MIC. The $\mathrm{n}$-hexane fraction achieved total mortality against C. albicans after $120 \mathrm{~min}$ at $1 \times$ MIC. The maximum amount of proteins $(0.566 \mu \mathrm{g} / \mathrm{ml})$ was released from $K$. pneumoniae by an n-butanol fraction at $2 \times$ MIC after $120 \mathrm{~min}$ of treatment while the maximum amount of nucleotides released $(4.575 \mu \mathrm{g})$ was from B. pumilus by n-hexane fraction under similar condition. Furthermore, membrane disruption has also been confirmed in the course of this study as one of the mechanisms of biocidal action of the leaf extract [81].

\section{CONCLUSION}

The ethnomedicinal applications of E. crispa were shown to be quite broad, ranging from cultural to treatment of wounds and epilepsy. The overall results suggest that E. crispa has $A \beta$ lowering effects, antibacterial, antidiarrheal, antifungal, and cell membrane disruption activities. Some of these pharmacological activities corroborate ethnomedicinal applications of the species throughout its distributional range. It is clear that several ethnomedicinal applications of E. crispa still require phytochemical and pharmacological validation. Any future research on the species should correlate the ethnomedicinal uses of E. crispa with its phytochemistry and pharmacological properties. Such ethnopharmacological research should also assess the mechanisms of actions, clinical effectiveness, and toxicological properties of the species.

\section{ACKNOWLEDGMENTS}

The author would like to express his gratitude to the National Research Foundation, South Africa and Govan Mbeki Research and Development Centre, University of Fort Hare for financial support to conduct this study.

\section{AUTHOR'S CONTRIBUTION}

Author declare that this work was done by the author named in this article.

\section{CONFLICTS OF INTEREST}

No conflicts of interest are associated with this work.

\section{REFERENCES}

1. Wallnöfer B. The biology and systematics of Ebenaceae: A review. Ann Naturhist Mus Wien 2001;103B:485-512.

2. Duangjai S, Wallnöfer B, Samuel R, Munzinger J, Chase MW. Generic delimitation and relationships in Ebenaceae sensu lato: Evidence from six plastid DNA regions. Am J Bot 2006;93:1808-27.

3. Wiart C. Medicinal Plants of Asia and the Pacific. Boca Raton: CRC Press; 2006.

4. Trease GE, Evans WC. Pharmacognosy. London: Baillière Tindall; 1983.

5. Mallavadhani UV, Panda AK, Rao YR. Pharmacology and chemotaxonomy of diospyros. Phytochemistry 1998;49:901-51.

6. Lim TK. Edible Medicinal and Non-medicinal Plants. Fruits. Vol. 2. London: Springer; 2012.

7. Hutchings A, Scott AH, Lewis G, Cunningham AB. Zulu Medicinal Plants: An Inventory. Pietermaritzburg: University of Natal Press; 1996.

8. Maroyi A. Review of ethnomedicinal uses, phytochemistry and pharmacological properties of Euclea natalensis A.DC. Molecules 2017;22:pii: E2128.

9. Maroyi A. Euclea undulata Thunb.: Review of its botany, ethnomedicinal uses, phytochemistry and biological activities. Asian Pac J Trop Med 2017;10:1030-6.

10. Jacot-Guillarmod A. Flora of Lesotho. Lehre: J Cramer; 1971

11. Palmer E, Pitman P. Trees for Southern Africa Covering all Known Indigenous Species in Republic of South Africa, South West Africa, Botswana, Lesotho and Swaziland. Cape Town: A.A. Balkema; 1972.

12. Gelfand M, Mavi S, Drummond RB, Ndemera B. The Traditional Medical Practitioner in Zimbabwe: His Principles of Practice and Pharmacopoeia. Gweru: Mambo Press; 1985.

13. Dzerefos CM, Witkowski ET. Density and potential utilization of medicinal grassland plants from Abe bailey nature reserve, South Africa. Biod Cons 2001;10:1875-96.

14. Moteetee A, Van Wyk BE. The medical ethnobotany of Lesotho: A review. Bothalia 2011;41:209-28.

15. Chinsamy M, Koitsiwe M. Traditional knowledge of medicinal and food plant uses for sustainable community livelihoods: A case of Batswana communities in South Africa. J Soc Sci 2016;46:146-54.

16. Dlamini CS, Geldenhuys CJ. The socioeconomic status of the nontimber forest product subsector in Swaziland. Southern For J For Sci 2009;71:311-8.

17. Van Wyk AE, Van Wyk P. Field Guide to Trees of Southern Africa. Cape Town: Struik Publishers (Pty) Ltd.; 1997.

18. Njuguna PM. Euclea divinorum Hiern. In: Jansen PC, Cardon D, editors. Plant Resources of Tropical Africa 3: Dyes and Tannins. Leiden: PROTA Foundation, Backhuys Publishers; 2005. p. 76-9.

19. Liengme CA. Plants used by the Tsonga people of Gazankulu. Bothalia 1981;18:501-8.

20. Moteetee A. A review of plants used for magic by Basotho people in comparison with other cultural groups in southern Africa. Indian J Trad Knowl 2017;16:229-34.

21. Breebaart L. Resource Overlap within a Guild of Browsing Ungulates in a South African Savanna. MSc Dissertation. Pietermaritzburg: University of Natal; 2000

22. Wiseman R. Woody Vegetation Change in Response to Browsing in Ithala Game reserve, South Africa. MSc Dissertation. Cape Town: University of Cape Town; 2001.

23. Breebaart L, Bhikraj R, O’Connor TG. Dietary overlap between Boer goats and indigenous browsers in a South African savanna. Afr J Range For Sci 2002;19:13-20

24. Wiseman R, Page BR, O'Connor TG. Woody vegetation change in response to browsing in Ithala Game Reserve, South Africa. S Afr J Wildlife Res 2004;34:25-37.

25. Dludla SP. The Effect of Condensed Tannins on Goats' Body Weight. MSc Dissertation. Kwadlengezwa: University of Zululand; 2010.

26. Botha J, Weiersbye IM. Ethnobotanic and forage uses of plants on mine properties in the Witwatersrand basin gold fields, South Africa. In: Fourie A, Tibbett M, Wiertz J, editors. Mine Closure. Perth: Australian Centre for Geomechanics; 2010. p. 325-42.

27. Chepape RM, Mbatha KR, Luseba D. Local use and knowledge validation of fodder trees and shrubs browsed by livestock in Bushbuckridge area, South Africa. Livestock Res Rural Dev 2011;23. Available from: http://www.lrrd.org/lrrd23/6/chep23132.htm. [Last accessed on 2017 Feb 24]

28. Maroyi A. The gathering and consumption of wild edible plants in Nhema communal area, midlands province, Zimbabwe. Ecol Food Nutr 
2011;50:506-25

29. Fomum SW. Diet Selection and Foraging Efficiency of Nguni Goats in the Bushveld of Gauteng, South Africa. MSc Dissertation. Pietermaritzburg: University of Natal; 2012.

30. Monegi P. Effects of Nutrient-tannin Interactions on Intake and Germination of Woody Plant Species by ruminants. MSc Dissertation. Pretoria: University of South Africa; 2017.

31. Van Wyk BE, Gorelik B. The history and ethnobotany of cape herbal teas. S Afr J Bot 2017;110:18-38.

32. Williams VL, Balkwill K, Witkowski ET. A lexicon of plants traded in the Witwatersrand umuthi shops. Bothalia 2001;31:71-98

33. Sasi S, Anjum N, Tripathi YC. Ethnomedicinal, phytochemical and pharmacological aspects of Flacourtia jangomas: A review. Int J Pharm Pharm Sci 2018;10:9-15.

34. White F. Ebenaceae. In: Launert E, editor. Flora Zambesiaca. Vol. 7. London: Flora Zambesiaca Managing Committee; 1983. p. 248-300.

35. White F, Verdcourt B. Ebenaceae. In: Polhill RM, editor. Flora of Tropical East Africa. Rotterdam: AA Balkema; 1996. p. 1-53.

36. Palgrave MC. Keith Coates Palgrave trees of southern Africa. $3^{\text {rd }}$ ed. Cape Town: Struik Publishers (Pty) Ltd.; 2002.

37. Mapaura A, Timberlake J. A Checklist of Zimbabwean Vascular Plants. Pretoria: Southern African Botanical Diversity Network Report No. 33, SABONET; 2004.

38. Setshogo MP. Preliminary Checklist of the Plants of Botswana. Pretoria: Southern African Botanical Diversity Network Report No. 33, SABONET; 2005

39. Germishuizen G, Meyer NL, Steenkamp Y, Keith MA. A Checklist of South African Plants. Pretoria: Southern African Botanical Diversity Network Report No. 41, SABONET; 2006.

40. Stoll A. Euclea crispa (Thunb.) Gürke Subsp. Crispa. Available from: http://www.pza.sanbi.org/euclea-crispa. [Last accessed on 2017 Sep 13].

41. Schmidt E, Lotter M, McCleland W. Trees and shrubs of Mpumalanga and Kruger National Park. Johannesburg: Jacana; 2002.

42. Voigt W. Euclea undulata Thunb. Karoo Desert National Botanical Garden; 2013. Available from: http://www.pza.sanbi.org/eucleaundulata. [Last accessed on 2017 Jul 13].

43. Tsvuura Z, Nyamhanga E. A preliminary checklist of plants from the Mazowe Botanic Reserve, Zimbabwe. Kirkia 2002;18:49-62.

44. Sibanda S, Mebe PP, Multari G. Pentacyclic triterpenoids from Euclea crispa. Fitoterapia 1992;63:274-7.

45. Masoga MA. Critical reflections on selected local narratives of contextual South African indigenous knowledge. In: Ngulube P, editor. Handbook of Research on Theoretical Perspectives on Indigenous Knowledge Systems in Developing Countries. Hershey PA: IGI Global; 2017. p. 310-31.

46. Long C. Swaziland's Flora: SiSwati Names and uses. Swaziland National Trust Commission; 2005. Available from: http:/www.sntc. org.sz/index.asp. [Last accessed on 2017 May 23].

47. Bryant AT. Zulu medicine and Medicine-Men. Cape Town: C. Struik; 1966.

48. Maja L, Masia T, Binyane K, Ramathebane M. Assessment of patient counselling in diabetic and hypertensive patients in terms of patient knowledge about their medication, disease state and lifestyle modifications by pharmacy personnel at LDF clinic in Maseru. Int J Pharm Pharm Sci 2018;10:155-61

49. Bossard E. La Médecinetraditionnelle au Centre et à L'ouest de L'angola. Lisboa: Ministério da Ciênciae da Tecnologia, Instituto de Investigaçâo Cientifica Tropical; 1996.

50. Schmitz MO. Wild Flowers of Lesotho. Roma: ESSA; 1982.

51. Morris B. Chewa Medical Botany: A Study of Herbalism in Southern Malawi. Hamburg: Lit Verlag; 1996.

52. Fowler DG. Traditional Fever Remedies: Alist of Zambian Plants; 2006. Available from: http://www.giftsofhealth.org/ritam/news/Traditional Fever remedie1.pdf. [Last accessed on 2017 Sep 13].

53. Vhurumuku E. Knowledge, use and attitudes towards medicinal plants of pre-service teachers at a South African university. Glob Adv Res J Env Sci Toxicol 2015;4:15-24.

54. Semenya SS, Potgieter MJ, Erasmus LJ. Indigenous plant species used by Bapedi healers to treat sexually transmitted infections: Their distribution, harvesting, conservation and threats. S Afr J Bot 2013;87:66-75.

55. Semenya SS, Potgieter MJ, Erasmus LJ. Bapediphytomedicine and their use in the treatment of sexually transmitted infections in Limpopo Province, South Africa. Afr J Pharm Pharmacol 2013;7:250-62.

56. Maroyi A. Alternative medicines for HIV/AIDS in resource-poor settings: Insight from traditional medicines use in sub-Saharan Africa. Trop J Pharm Res 2014;13:1527-36.
57. Tshikalange TE, Mophuting BC, Mahore J, Winterboer S, Lall N. An ethnobotanical study of medicinal plants used in villages under Jongilanga tribal council, Mpumalanga, South Africa. Afr J Tradit Complement Altern Med 2016;13:83-9.

58. Maroyi A, Rasethe MT. Comparative use patterns of plant resources in rural areas of South Africa and Zimbabwe. Phyton Int J Exp Bot 2015;84:288-97.

59. Kokwaro JO. Medicinal plants of East Africa. Nairobi: Kenya Literature Bureau; 1993

60. Majinda RR, Motswaledi MS. Antibiotic activity of selected Botswana medicinal plants. Botsw Notes Rec 1998;30:157-61.

61. Bandeira SO, Gaspar F, Pagula FP. African ethnobotany and healthcare: Emphasis on Mozambique. Pharm Biol 2001;39 Suppl 1:70-3.

62. Moshi MJ, Mbwambo ZH, Nondo RS, Masimba PJ, Kamuhabwa A, Kapingu MC, et al. Evaluation of ethnomedical claims and brine shrimp toxicity of some plants used in Tanzania as traditional medicines. Afr J Trad Complem Altern Med 2006;3:48-58

63. More G, Tshikalange TE, Lall N, Botha F, Meyer JJ. Antimicrobial activity of medicinal plants against oral microorganisms. J Ethnopharmacol 2008;119:473-7.

64. Mbanga J, Ncube M, Magumura A. Antimicrobial activity of Euclea undulata, Euclea divinorum and diospyroslycioides extracts on multidrug resistant Streptococcus mutans. J Med P1 Res 2013; 7:2741-6.

65. Motlhanka DM, Nthoiwa GP. Ethnobotanical survey of medicinal plants of Tswapong North, in eastern Botswana: A case of plants from Mosweu and Seolwane villages. Eur J Med P1 2013;3:10-24.

66. Chauke MA, Shai LJ, Mogale MA, Tshisikhawe MP, Mokgotho MP. Medicinal plant use of villagers in the Mopani district, Limpopo province, South Africa. Afr J Trad Complem Altern Med 2015;12:9-26.

67. Ngarivhume T, Van'tKlooster CI, De Jong JT, Westhuizen JH. Medicinal plants used by traditional healers for the treatment of malaria in the Chipinge district in Zimbabwe. J Ethnopharmacol 2015;159:224-37.

68. Posthouwer C. Medicinal Plants of Kariakoomarket, Dar es Salaam, Tanzania. MSc Dissertation. Leiden: Leiden University; 2015.

69. Maroyi A. An ethnobotanical survey of medicinal plants used by the people in Nhema communal area, Zimbabwe. J Ethnopharmacol 2011;136:347-54.

70. Maroyi A. Traditional use of medicinal plants in south-central Zimbabwe: Review and perspectives. J Ethnobiol Ethnomed 2013;9:31.

71. Steenkamp V. Traditional herbal remedies used by South African women for gynaecological complaints. J Ethnopharmacol 2003;86:97-108.

72. Van Wyk BE, Gericke N. People's Plants: Aguide to Useful Plants of Southern Africa. Pretoria: Briza Publications; 2000

73. Graham JG, Quinn ML, Fabricant DS, Farnsworth NR. Plants used against cancer: An extension of the work of Jonathan Hartwell. J Ethnopharmacol 2000;73:347-77.

74. Grace OM, Prendergast HD, Jäger AK, Van Staden J. Bark medicines in traditional healthcare in KwaZulu-Natal, South Africa: An inventory. S Afr J Bot 2002:69:301-63.

75. Deutschländer MS, Lall N, Van de Venter M, Dewanjee S. The hypoglycemic activity of Euclea undulata Thunb. Var. Myrtina (Ebenaceae) root bark evaluated in a streptozotocin-nicotinamide induced Type 2 diabetes rat model. S Afr J Bot 2012;80:9-12.

76. Kwon HC, Cha JW, Park JS, Chun YS, Moodley N, Maharaj VJ, et al. Rapid identification of bioactive compounds reducing the production of Amyloid $\beta$-Peptide $(A \beta)$ from South African plants using an automated HPLC/SPE/HPLC coupling system. Biomol Ther 2011;19:90-6.

77. España J, Valero J, Miñano-Molina AJ, Masgrau R, Martín E, Guardia-Laguarta C, et al. $\beta$-amyloid disrupts activity-dependent gene transcription required for memory through the CREB coactivator CRTC1. J Neurosci 2010;30:9402-10.

78. Pretorius PC, Magama S, Zietsman PC. Growth inhibition of plant pathogenic bacteria and fungi by extracts from selected South African plant species. S Afr J Bot 2003;69:186-92.

79. Pretorius PC, Magama S, Zietsman PC. Purification and identification of antibacterial compounds from Euclea crispa subsp. Crispa (Ebenaceae) leaves. S Afr J Bot 2003;69:579-86.

80. Magama S, Pretorius JC, Zietsman PC. Antimicrobial properties of extracts from Euclea crispa subsp. Crispa (Ebenaceae) towards human pathogens. S Afr J Bot 2003;69:193-8.

81. Alayande KA, Pohl CH, Ashafa AO. Time-kill kinetics and biocidal effect of Euclea crispa leaf extracts against microbial membrane. Asian Pac J Trop Med 2017;10:390-9.

82. Alayande KA, Pohl CH, Ashafa AO. Assessment of anti-diarrhoea properties of Euclea crispa (Thunb.) leaf extract and fractions. S Afr J Bot 2016;103:306. 